\title{
THE FIRST RECORD OF THE FAMILY PARANTENNULIDAE (ACARI, MESOSTIGMATA) IN UKRAINE WITH REDESCRIPTION OF FEMALE OF PARANTENNULUS SCOLOPENDRARUM
}

\author{
V. A. Trach \\ I. I. Mechnikov Odessa National University, \\ Shampanskij al., 2, Odessa, 65058 Ukraine \\ E-mail: listoed@rambler.ru
}

Received 15 November 2010

Accepted 15 July 2011

The First Record of the Family Parantennulidae (Acari, Mesostigmata) in Ukraine with Redescription of Female of Parantennulus scolopendrarum. Trach V. A. - Mites of the family Parantennulidae are recorded from Ukraine for the first time. A female of Parantennulus scolopendrarum (Berlese, 1886) from the megarian banded centipede Scolopendra cingulata (Latreille, 1829) is redesribed.

Key words: Parantennulidae, Parantennulus scolopendrarum, Ukraine, Scolopendra cingulata.

Первая находка семейства Parantennulidae (Acari, Mesostigmata) в Украине с переописанием самки Parantennulus scolopendrarum. Трач В. А. - Клещи семейства Parantennulidae впервые обнаружены в Украине. Переописана самка Parantennulus scolopendrarum (Berlese, 1886) с кольчатой сколопендры Scolopendra cingulata (Latreille, 1829).

Ключевые слова: Parantennulidae, Parantennulus scolopendrarum, Украина, Scolopendra cingulata.

\section{Introduction}

Two of the five described species of Parantennulidae (Acari, Mesostigmata, Trigynaspida, Antennophorina) were known from myriapods in Europe ( $P$. scolopendrarum (Berlese, 1886) on centipedes and Diplopodophilus antennophoroides Willman, 1940 on millipedes), three species of the genus Micromegistus Тrдgerdh, 1948 are associated with carabid beetles in the Americas, Australia and New Zealand (Lindquist et al., 2009; Kim, Castagnoli, 2010).

A species of the family Parantennulidae was collected in Odessa Region in 2010 on megarian banded centipede Scolopendra cingulata (Latreille, 1829) (Chilopoda, Scolopendromorpha, Scolopendridae). It was then identified to be Parantennulus scolopendrarum (Berlese, 1886). Mites of the family Parantennulidae are recorded from Ukraine for the first time.

$P$. scolopendrarum was originally described from megarian banded centipede in Florence (Italy) as Antennophorus scolopendrarum Berlese, 1886. Later it was designated as the type species of the genus Parantennulus Berlese, 1904 (Berlese, 1886, 1892, 1904). The species was known only from Italy. Previous descriptions of $P$. scolopendrarum were incomplete, without detailed drawings (Berlese, 1886, Kim, Castagnoli, 2010).

\section{Material and methods}

Large specimens of Scolopendra cingulata (Latreille, 1829), the species widespread in the Mediterranean region, southern part of Ukraine, Moldova, Northern Caucasus and Transcaucasia, and the western part of Central Asia (Zalesskaya, Shileiko, 1991) and common in the steppe part of Odessa Region, were collected from under stones and placed in the vials containing $70 \%$ ethyl alcohol. About 30 specimens of centipedes from three collection sites were observed; mites were found in two sites. Mites were removed from centipedes and mounted on microslides in Hoyer's medium. Slides were studied by means of the light microscope Mikmed-1 Lomo. The morphological terminology follows Evans, Till (1979). Measurements are given in micrometers $(\mathrm{mkm})$. All microslides are deposited in the collections of the Department of Zoology, I. I. Mechnikov Odessa National University. 


\section{Results and discussion}

Only females of $P$. scolopendrarum were found on myriapods. The males and immature stages of this mite remain undescribed. Mites were located mainly on the pleural region of the trunk segments and sometimes on the legs of $S$. cingulata. Mites were found on five centipedes, the number of specimens of mites collected on one S. cingulata varied between $1-8(1 ; 1 ; 3 ; 4 ; 8)$. P. scolopendrarum is known from Italy and Ukraine now. The distribution of $P$. scolopendrarum coincides with distribution of $S$. cingulata probably.

\section{Parantennulus scolopendrarum (Berlese 1886)}

Material. Ukraine, Odessa Region: Kominternovsky distr., vic. of Vapnyarka, $46^{\circ} 35^{\prime} \mathrm{N} 30^{\circ} 53^{\prime} \mathrm{E}$, 6.04.2010, 1 \%; same data, 26.09.2010, 4 \%; Ukraine Odessa Region: Belyaevsky distr., vic. of Holodnaya Balka, 46 35' N 30 36' E, 2.05.2010, 12 o (V. A. Trach leg.).

Redescription. Female. Dorsum (fig. 1, 1). Idiosoma yellow, egg-shaped (754-846 × 626-708 mkm). Dorsal shield brown, rounded pentagonal, covering about half of dorsal surface $(607-681 \times 451-515 \mathrm{mkm})$, with reticulate ornamentation, bearing 16 pairs of setae $(17-76 \mathrm{mkm})$ and some pores or lyrifissures, including one unpaired, located on anterior part of shield. Most setae on dorsal shield weakly serrate. One pair of narrow pygidial sclerites located behind dorsal shield $(4-6 \times 27-34 \mathrm{mkm})$. Each side of idiosoma with one pair of rounded sclerites (diameter 17-21 mkm). Lateral soft cuticle with about 20 pairs of setae $(15-76 \mathrm{mkm})$ on small rounded sclerites. Setae located near dorsal shield similar in shape to setae of dorsal shield, setae located on margins of idiosoma shorter and thicker. Anal opening terminal, anal shield partially visible from above.

Venter (fig. 2, 1). Tritosternum with short and narrow base $(11-13 \times 21-27 \mathrm{mkm})$ with two free and pilose laciniae (90-99 mkm long). Sternal shield well sclerotized, short and wide $(13-19 \times 132-145 \mathrm{mkm})$, bearing two pairs of long serrare setae $(34-55$ $\mathrm{mkm}$ ) (all our specimens with only two pairs of setae on shield, although three pairs of setae on sternal shield were mentioned in Berlese's original description). Two pairs of subequal setae posterior of sternal shield at level of legs II. Latigynial shields weakly sclerotized with striate sculpture, bearing one pair of smooth setae $(23-27 \mathrm{mkm})$. Mesogynial shield well sclerotized, rounded trapezoid $(71-86 \times 147-164 \mathrm{mkm})$, its anterior edge usually slightly concave, 2-4 fossulae near shield center. Mesogynial shield with one pair of smooth setae and usually with one-three unpaired setae (21-27 $\mathrm{mkm}$ ), some of unpaired setae can be located outside of the shield (fig. 1, 2). A well visible sclerotized structures are present under the shield. Ventral shield well sclerotized, reticulated, large $(285-322 \times 368-414 \mathrm{mkm})$, with $10-11$ thickened setae $(23-40$ $\mathrm{mkm}$ ), most of them are paired (in the original description ventral shield with 17 setae) (fig. 1, 3). One pair of narrow sclerites similar in shape to pygidial sclerites $(27-34 \times$ 4-6 $\mathrm{mkm}$ ) posterior to ventral shield. Opisthogastric setae (about 15 pair) on small rounded sclerites, some setae serrated $(19-69 \mathrm{mkm})$. Anal shield small $(59-63 \times 67-74$ $\mathrm{mkm}$ ), with large anus and one pair of preanal smooth thin setae $(34-40 \mathrm{mkm})$ (fig. 1, 4). Peritremes short (124-139 mkm), peritremal shields fused with endopodal and exopodal shields. Endopodal part of shield at level of legs III with sclerotized structure. Peritrematal shield fused with dorsal shield anteriorly.

Gnathosoma (fig. 1, 5). Tectum short, with triangular asymmetrical apex (fig. 1, $6)$. Corniculi, internal and external malae long, serrate. Anterior hypostomal seta spinelike $(21-25 \mathrm{mkm})$, external posterior hypostomal seta $(21-25 \mathrm{mkm})$, internal posterior hypostomal seta $(21-23 \mathrm{mkm})$ and palpcoxal seta $(23-27 \mathrm{mkm})$ serrate. Chaetotaxy of palps (from trochanter to genu): 2-5-5. Many setae on palps spine-like, barbed and serrate. Palptarsal apotele 2-tined. Length of palps (trochanter to tarsus) - 


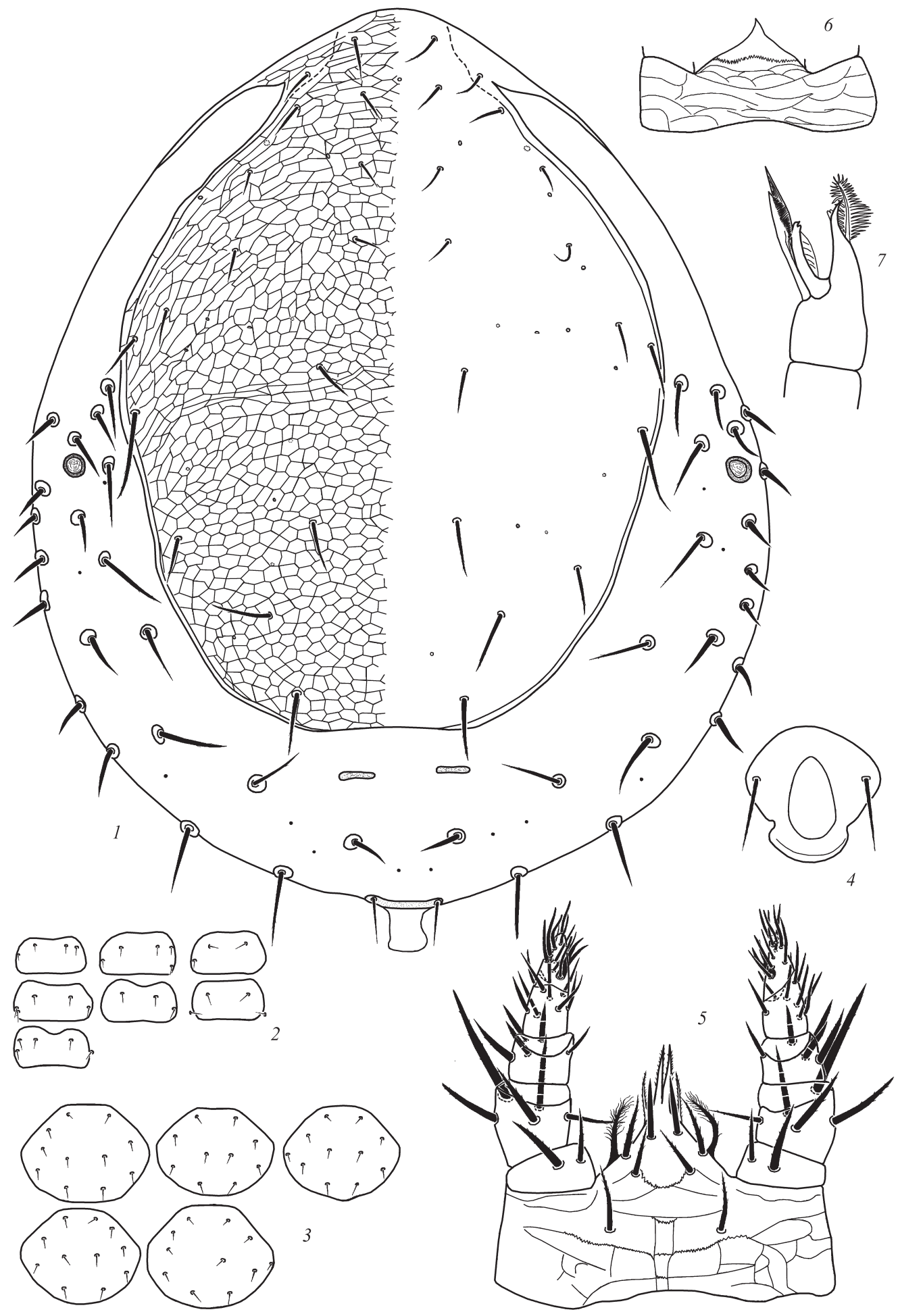

Fig. 1. Parantennulus scolopendrarum, o: $1-$ idiosoma, dorsal view; 2 - variants of the arrangement of setae on the mesogynal shield; 3 - variants of the arrangement of setae on the ventral shield; 4 - anal shield; $5-$ gnathosoma; 6 - tectum; 7 - chelicera.

Рис. 1. Parantennulus scolopendrarum, о: 1 - идиосома, дорсально; 2 - варианты расположения щетинок на мезогинальном щите; 3 - варианты расположения щетинок на вентральном щите; $4-$ анальный щит; 5 - гнатосома; $6-$ тектум; 7 - хелицера. 


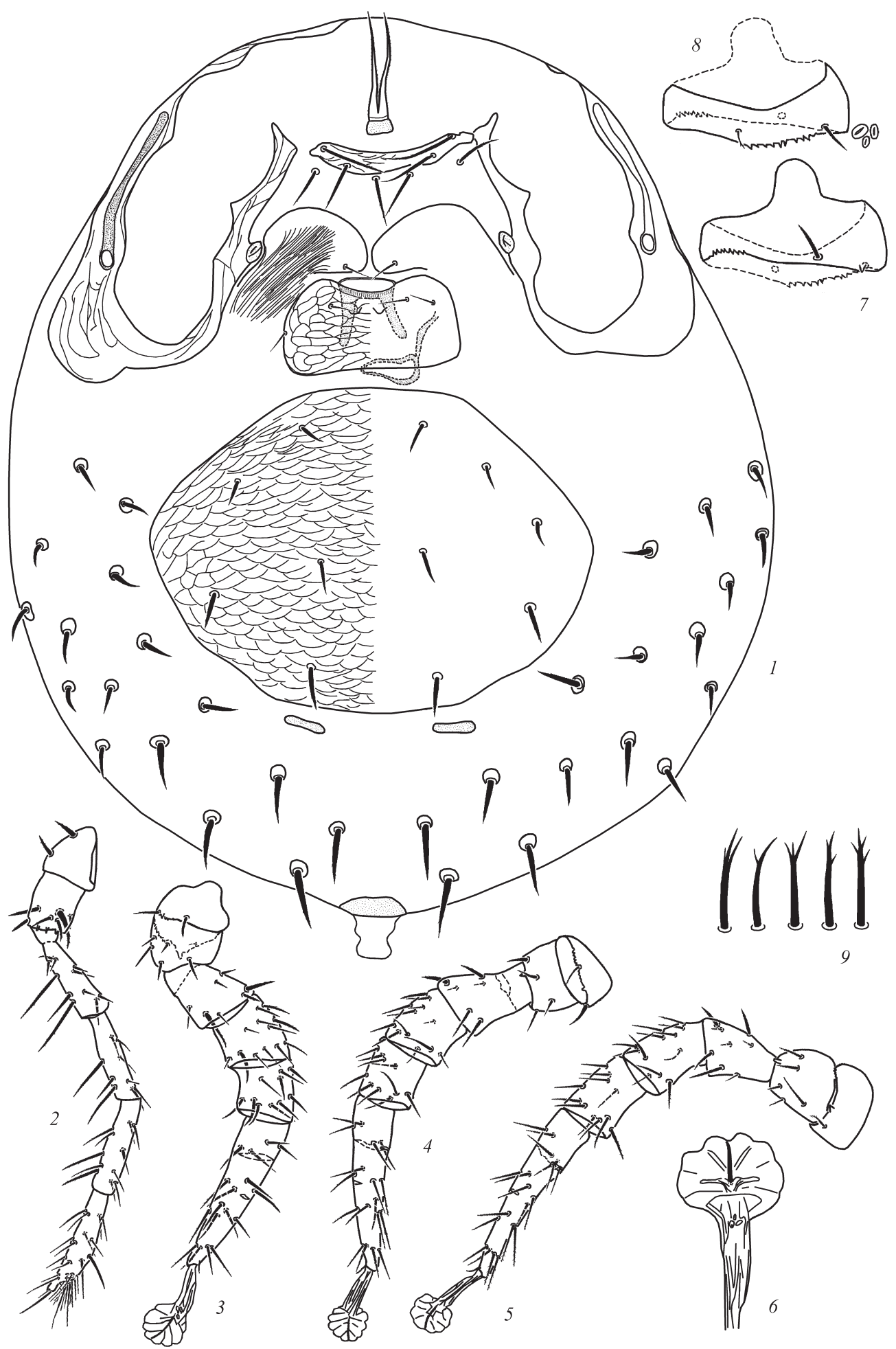

Fig. 2. Parantennulus scolopendrarum, o: 1 - idiosoma, ventral view; 2-5 - legs I-IV, respectively; $6-$ ambulacrum; 7 - coxa II, ventral view; 8 - coxa II, dorsal view; 9 - variety of forms of additional setae on coxa II.

Рис. 2. Parantennulus scolopendrarum, о: 1 - идиосома, вентрально; 2-5 - ноги I-IV, соответственно; 6 - амбулакрум; 7 - тазик II, вентрально; 8 - тазик II, дорсально; 9 - изменчивость формы дополнительной щетинки на тазике II. 
118-124 mkm. Length of second cheliceral segment (to tip of fixed digit) - 74-80 $\mathrm{mkm}$. Movable digit of chelicera with two excrescences, fixed digit with distal processes and fimbriate dorsal excrescence (fig. 1, 7).

Legs (fig. 2, 2-5). Leg I without ambulacrum and claws. Leg II-IV with ambulacrum and thin claws (fig. 2, 6). Leg chaetotaxy (from coxa to tibia): I 2-6-11-9-11, II - 3-5-7-12-10, III - 2-4-6-12-10, IV - 1-5-8-12-11. Coxa II with two usual ventral setae $(27-44 \mathrm{mkm})$ and one additional small 2-4-tined dorsal seta (13-19 mkm) (fig. 2, 7-9). Tarsus of leg IV with ventral intercalary sclerite. Most leg setae serrate, some setae thickened. Length of legs (from coxa to tarsus with ambulacrum ): I - 616-644, II - 664-727, III - 664-708, IV - 699-782 mkm.

My sincere thanks are due to Dr. Owen Seeman (Queensland Museum, South Brisbane, Australia) for sending me original Berlese's description of P. scolopendrarum. I also thank Dr. A. A. Khaustov (Nikita Botanical Garden, Yalta, Ukraine) for improvement in English text of the early version of the manuscript.

Berlese A. Acari, Myriopoda et Scorpiones ucusque in Italia Fascicolo. - Padova, 1886. - Fasc. 31, N 9.

Berlese A. Acari, Myriopoda et Scorpiones hucusque in Italia reperta. Fasc. 3. Ordo Mesostigmata (Gamasidae). - Patavii : Sumptibus Auctoris, 1892. - 143 p.

Berlese A. Illustrazione iconografica degli Acari mirmecofili // Redia. - 1904. - 1. - P. 299-474.

Evans G. O., Till W. M. Mesostigmatic mites of Britain and Ireland (Chelicerata: Acari-Parasitiformes). An introduction to their external morphology and classification // Trans. Zool. Soc. Lond. - 1979. 35. - P.139-270.

Kim C.-M., Castagnoli M. Parantennulidae: what's in the family? (Acari: Mesostigmata: Trigynaspida) // International journal of acarology. - 2010. - 36, N 5. - P. 409-412.

Lindquist E. E., Walter D. E., Krantz G. W. Chapter twelve. Order Mesostigmata // A manual of acarology. Third edition / Eds. G. W. Krantz, D. E. Walter. - Lubbock, Texas : Texas Tech University Press, 2009. - P. 124-232.

Zalesskaya N. T., Shileiko A. A. The scolopendromorph centipedes (Chilopoda, Scolopendromorpha). Moscow : Nauka, 1991. - 103 p. - Russian : Залесская Н. Т., Шилейко А. А. Сколопендровые многоножки (Chilopoda, Scolopendromorpha). 